University of Nebraska - Lincoln

DigitalCommons@University of Nebraska - Lincoln

\title{
Use of Environmental Scanning Electron Microscopy for in situ Observation of Interaction of Cells with Micro- and Nanoprobes
}

\author{
Alexander Goponenko \\ University of Nebraska-Lincoln, agoponenko2@unl.edu \\ B. J. Boyle \\ University of Nebraska-Lincoln \\ K. I. Jahan \\ University of Nebraska-Lincoln, s-kjahan1@unl.edu \\ Maxim V. Gerashchenko \\ Harvard Medical School \\ Dmitri E. Fomenko \\ University of Nebraska-Lincoln, dfomenko2@unl.edu \\ See next page for additional authors
}

Follow this and additional works at: https://digitalcommons.unl.edu/mechengfacpub

Part of the Mechanics of Materials Commons, Nanoscience and Nanotechnology Commons, Other Engineering Science and Materials Commons, and the Other Mechanical Engineering Commons

Goponenko, Alexander; Boyle, B. J.; Jahan, K. I.; Gerashchenko, Maxim V.; Fomenko, Dmitri E.; Gladyshev, Vadim N.; and Dzenis, Yuris A., "Use of Environmental Scanning Electron Microscopy for in situ Observation of Interaction of Cells with Micro- and Nanoprobes" (2011). Mechanical \& Materials Engineering Faculty Publications. 88.

https://digitalcommons.unl.edu/mechengfacpub/88

This Article is brought to you for free and open access by the Mechanical \& Materials Engineering, Department of at DigitalCommons@University of Nebraska - Lincoln. It has been accepted for inclusion in Mechanical \& Materials Engineering Faculty Publications by an authorized administrator of DigitalCommons@University of Nebraska Lincoln. 


\section{Authors}

Alexander Goponenko, B. J. Boyle, K. I. Jahan, Maxim V. Gerashchenko, Dmitri E. Fomenko, Vadim N. Gladyshev, and Yuris A. Dzenis 


\title{
Use of Environmental Scanning Electron Microscopy for in situ Observation of Interaction of Cells with Micro- and Nanoprobes
}

\author{
A. V. Goponenko, ${ }^{1}$ B. J. Boyle, ${ }^{1}$ K. I. Jahan, ${ }^{1}$ M. V. Gerashchenko, ${ }^{2}$ \\ D. E. Fomenko, ${ }^{3}$ V. N. Gladyshev, ${ }^{2}$ and Y. A. Dzenis ${ }^{1}$ \\ 1. Nanofiber Facility, Department of Engineering Mechanics and Nebraska Center for Materials and Nanoscience, \\ University of Nebraska-Lincoln, Lincoln, NE 68588-0526, USA \\ 2. Department of Medicine, Brigham and Women's Hospital, Harvard Medical School, 77 Ave. Louis Pasteur, Boston, MA 02115, USA \\ 3. Department of Biochemistry, University of Nebraska-Lincoln, Lincoln, NE 68588-0664, USA \\ Corresponding author - Y. Dzenis, email ydzenis@unl.edu
}

\begin{abstract}
Precision intracellular sensing, probing and manipulation offer unprecedented opportunities for advances in biological sciences. Next-generation ultra-fine probes will be capable of targeting individual cell organelles. Development of such probes as well as probes capable of penetrating through tough cell walls requires detailed knowledge of cell-probe interaction. This Letter evaluated the applicability of environmental scanning electron microscopy (ESEM) for cell and cell-probe interaction imaging. Several types of cells (plant and yeast cells as well as mouse spermatozoa) were successfully imaged in their natural state, with mouse spermatozoa observed by ESEM for the first time. Computerized stage applied to image was tough plant cell walls interactions with several probes. Substantial damage to the cell walls was observed as a result of microprobe penetration. The damage persisted after the probe withdrawal and there was residue of cellular content on the withdrawn probes. Several mechanisms of probe failure were observed in situ global buckling, localized bending followed by the tip break-off, and plastic deformation with permanent bending in the case of ultra-fine metal nanoprobe. The results demonstrate applicability of ESEM for high-resolution in situ imaging of cells. Observed mechanisms of cell damage and probe failure provide guidance for future development of probes for minimally-invasive intercellular probing.
\end{abstract}

1. Introduction: Probing of cells with microprobes such as micropipettes is an important tool for the analysis of fundamental cellular processes. Cell interrogation with micropipettes enabled a patch-clamp technique that led to fundamental advances in understanding cell electrophysiology [1]. Micropipettes were also used to measure turgor pressure in cells [2] and are now widely used for cell microinjection. The latter made possible such important biomedical applications as intracytoplasmic sperm injection, pronuclear DNA injection, transgenic techniques, cloning and gene therapy [3-6].

Despite their wide use, the current microinjection probes and devices have significant limitations. The choice of materials for the microneedles is limited and restricted mostly to glass. The control of their size and shape by the available pulling techniques is also limited and the resulting brittle micropipettes bend and break easily [7], especially during penetration of cells with tough membranes or cell walls. The microcapillaries often cause damage to cells, which dramatically decreases the injection success rate $[8,9]$. Sealing of the plasma membrane around the microcapillary tip is often incomplete in small $(2-15 \mathrm{~mm})$ mammalian cells or in cells with high turgor pressure such as plant cells. Additionally, in cells with high turgor pressure, almost instantaneous release of cellular pressure after the penetration and partial evacuation of cellular content into the capillary can disrupt the cellular structure [9]. Other detrimental effects of microcapillaries, particularly on small or flat cells, include excessive membrane rupture, inaccurate transplant and fatal deformation of crucial organelles. Many of the problems described above can be traced to the relatively large size of micropipettes and microprobes used in the current techniques. Smaller, less invasive cell probes are needed to improve transfection efficiency, reduce cell damage and achieve efficient subcellular transfection $[9,10]$.

Precise minimally invasive intracellular sensing, probing and manipulation capable of targeting small cells, individual cell compartments and organelles and/or cells with tough walls is expected to lead to important advances in various areas of the life sciences. Currently, there is high inter- est in developing such probes using emerging nanomaterials and nanofabrication technologies. Continuous nanofibers fabricated by electrospinning represent one class of nanomaterials that appears particularly suitable for intracellular probing [11]. Such nanofibers can be prepared from a wide variety of materials including polymers, carbon and ceramics. Electrospun nanofibers are continuous (endlessly long) and their diameters can be varied in a broad range from a few nanometers to microns. Nanofibers can be aligned and precision-deposited [11] for easy incorporation into devices. Finally, co-axial electrospinning can be used for a one-step fabrication of composite nanofibers (e.g. multilayer nanofibers for multifunction/ mode probing) or hollow nanofibers (e.g. nanopipes for precision nanoinjection). Development of next-generation cellular nanoprobes will require detailed knowledge of mechanisms of cell-probe interactions. That, in turn, will require high-resolution dynamic in situ imaging of cells and probes.

Optical microscopy provides high versatility and imposes minimal constraints on the cell environment. However, its resolution and depth of focus may not be sufficient. Scanning probe microscopy achieves excellent resolution. However, the technique is relatively slow and has limited applicability for in situ imaging of cell probing owing to problems with scanning around the interrogating probe.

Scanning electron microscopy (SEM) is a well-established microscopy technique featuring high resolution (down to a few nanometers), good depth of field and ability to accommodate bulk specimens and in situ loading/probing devices. SEM is extensively employed for imaging and analysis of damage and fracture mechanisms in synthetic materials and devices [12-20]. However, harsh imaging chamber environment and specimen coating requirement of the conventional high-vacuum SEM systems normally preclude using this technique on hydrated biological subjects [21-25]. Applications on dehydrated or frozen specimens will not provide important information on cell response to probing and will also significantly exaggerate cell stiffness, thus providing incorrect information on mechanical feedback "felt" by the probe. 
Environmental scanning electron microscopy (ESEM) employs specialized electron detectors and differential pumping systems to allow gaseous environment in the specimen chamber. The ESEM can be used for imaging biological specimens in more natural state. Non-conductive and outgassing specimens, such as uncoated wet samples, may also be observed without preparation [26-28]. ESEM has been utilized for visualizing dynamic processes [29-35] and for manipulation and mechanical studies of a variety of subjects at the nanoscale [19, 21, 28, 36-39].

The goal of this study was to evaluate the applicability of the ESEM technique for cell imaging and in situ investigation of probe-cell interactions. Several types of cells, namely epidermal cells of plant leaves, budding yeast cells and mouse spermatozoa, were selected based on the challenges they pose to the existing microprobing and microinjection techniques. Appropriate specimen preparation protocols and imaging regimes were identified and developed and successful ESEM imaging of the hydrated cells was demonstrated. Interactions of several types of probes with epidermal plant cells was imaged in situ and the mechanisms of cell damage and probe failure were identified and documented for the first time. The results demonstrate the feasibility of the ESEM as a useful imaging method for the cell and probe-cell interaction analyses.

2. Experimental: Rationale for cell selection: Organisms and cells selected for this study included epidermal cells of Arabidopsis thaliana and Phaseolus vulgaris leaves, Saccharomyces cerevisiae cells, and mouse epidydymal spermatozoa. All three experimental cell systems present significant challenges for the existing methods of microinjection and microprobing. Plants are challenging targets for microinjection because of their tough cell walls. Microinjection of yeast cells, which in addition to having cell walls are small, has not yet been achieved with any of the currently available methods. Considering availability of state-of-the-art genetic tools for budding yeast, the ability to inject these cells would be especially useful. Spermatozoa represent an intermediate class of cells between the more robust cells with cell walls and more delicate cultured mammalian cells. They have no cell walls, but they are stabilized by the structural components of the sperm head, midpiece and tail and include condensed compartments for DNA delivery, energy production and movement. They also have complex shape and a small width comparable to that of yeast cell. Precision nanoprobing/injection of plant cells, yeast cells, and spermatozoa is expected to provide new insights on basic properties of these cells, their metabolism and functions, and it can be used for individual cell modification.

2.1. Selected cells: A. thaliana and P. vulgaris were grown in the Beadle Center Greenhouse, University of Nebraska-Lincoln. Fresh cut leaves were used for testing.

Wild-type S. cerevisiae cells in the BY4741 background were from Invitrogen and grown on YPD medium (2\% glucose, $2 \%$ peptone, $1 \%$ yeast extract and $2 \%$ agar for solid medium). Logarithmically grown centrifuged yeast cells were re-dispersed in distilled water and transferred on glass surface for testing.

Mouse spermatozoa were extracted from epidydymus into TALP solution $\left(5.69 \mathrm{~g} / 1 \mathrm{NaCl}, 0.23 \mathrm{~g} / 1 \mathrm{KCl}, 0.04 \mathrm{~g} / 1 \mathrm{Na}_{2} \mathrm{HPO}_{4^{\prime}}\right.$ $2.09 \mathrm{~g} / 1 \mathrm{NaHCO}_{3}, 0.08 \mathrm{~g} / 1 \mathrm{MgCl}_{2} \cdot \mathrm{H}_{2} \mathrm{O}, 0.29 \mathrm{~g} / 1 \mathrm{CaCl}_{2} \cdot 2 \mathrm{H}_{2} \mathrm{O}$, $0.02 \mathrm{~g} / 1$ sodium pyruvate, $0.90 \mathrm{~g} / 1$ glucose, $3.68 \mathrm{~g} / \mathrm{g}$ lactic acid, $2.38 \mathrm{~g} / 1$ HEPES, $6 \mathrm{~g} / 1$ bovine serum albumin and penicillin, U 20,000), and were kept frozen until used.

2.2. Methods: ESEM imaging was performed on FEI Quanta 200 FEG microscope co-located within UNL's Nanofiber Facility and Biomechanics, Biomaterials and Biomedicine (BM3) Instrumentation Facility. Cooling stage was set to $2-6^{\circ} \mathrm{C}$. Hu- midity was adjusted in the range from 60-95\%. Cell-probe interactions were studied in situ in ESEM mode using Gatan Microtest $200 \mathrm{~N}$ stage mounted inside SEM chamber and custom-designed cell- and probe-holding fixtures.

Fine glass pipettes were pulled using Narishige PC-10 Puller. Tungsten nanoprobes were produced from tungsten wires by electrochemical etching using a custom-made device at UNL.

\section{Results and discussion}

3.1. Imaging of cells with ESEM: Plants are protected by cell walls and may withstand mild dehydration. Such samples allow full utilization of advantages of ESEM and may even survive imaging in ESEM [27, 28].We were able to successfully image both selected types of plant cells without any special specimen preparation (Figures $1 a$ and $b$ ). The imaging regimes could be varied over broad ranges of parameters and very high resolution could be achieved.

Yeast cells have cell walls, although generally not as tough as the cell walls of plant cells. These cells are also substantially smaller in size and generally require higher magnification. We have imaged sheets of yeast cells under a wide range of accelerating voltage, spot size and humidity. It was observed that hydrated yeast cells could be destroyed by electron beam during high-resolution imaging at high energy of the beam. However, extensive parametric study conducted showed that highresolution imaging of yeast cells could be attained without any noticeable sample degradation at low energy of the electron beam or decreased humidity. Figure $1 c$ shows an example image obtained at accelerating voltage $5 \mathrm{kV}$ and spot size 2.0.

Spermatozoa can tolerate changes in the environment better than many other mammalian cell types. At the same time, spermatozoa do not tolerate dehydration and suffer from hypotonic damage at low osmotic pressure, thus requiring a culture medium. Imaging of these cells by ESEM can only be performed if the cells are on the surface. Such condition can be attained after most of the medium is removed, for example, by evaporation. When water evaporates from TALP, which is a common medium for spermatozoa, salts that are contained in the medium begin to crystallize and obscure ESEM image (see Figure $2 a$ ). To resolve this problem, we investigated two approaches. The first approach was to use a specially designed medium that, when partially evaporated, would not obscure the imaging in ESEM. In the second approach, the excess of TALP was absorbed using a porous substrate.

In the first approach, the new medium must maintain osmotic pressure but must not obscure the imaging after partial evaporation of water. Ammonium bicarbonate and ammonium acetate were previously suggested for the preparation of residue-free buffer for conventional SEM specimen

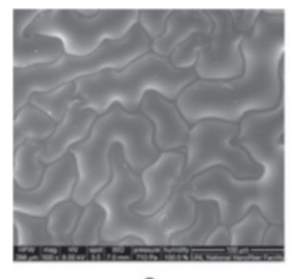

a

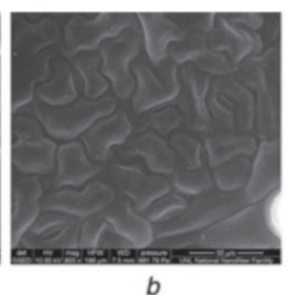

$b$

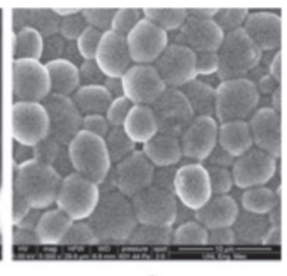

c
Figure 1. ESEM image of leaf surface. a. Arabidopsis (Arabidopsis thaliana) b. Common bean (Phaseolus vulgaris) c. Yeast (Saccharomyces cerevisiae) cells. Imaging parameters: (a) $8 \mathrm{kV}$ accelerating voltage (AV), 3.0 spot size (S), $710 \mathrm{~Pa}$ chamber pressure $(\mathrm{CP}), 2^{\circ} \mathrm{C}$ sample temperature (T), 100\% relative humidity $(\mathrm{H}), 298 \mu \mathrm{m}$ horizontal field width (HFW); (b) $10 \mathrm{kV}$ AC, $4.0 \mathrm{~S}, 680 \mathrm{~Pa} \mathrm{CP}, 2^{\circ} \mathrm{C} \mathrm{T}, 96 \% \mathrm{H}, 186 \mu \mathrm{m}$ HFW; (c) Highresolution image at low-energy beam ( $5 \mathrm{kV} \mathrm{AC}, 2.0 \mathrm{~S}, 29.8 \mu \mathrm{m} \mathrm{HFW})$ with no noticeable degradation of the sample. Other imaging parameters: $630 \mathrm{~Pa} \mathrm{CP}, 2^{\circ} \mathrm{C} \mathrm{T}, 89 \% \mathrm{H}$ 


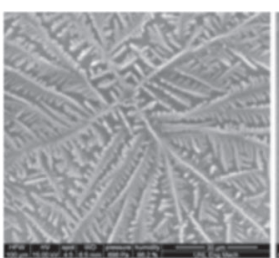

a

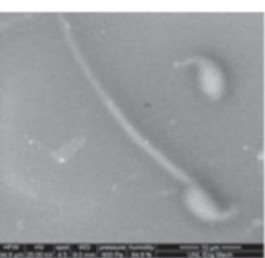

b

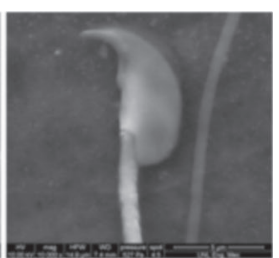

C
Figure 2. ESEM images of sperm cells. a. Image of a partially dried mouse sperm sample in TALP. Crystals are visible but no cells can be seen $b$. Image of a partially dried sperm sample in ammonium bicarbonate/ ammonium acetate buffer c. Image of a sperm specimen in TALP on Nuclepore substrate Imaging parameters: (a) $15 \mathrm{kV}$ AC, $4.5 \mathrm{~S}$, $700 \mathrm{~Pa} \mathrm{CP}, 2^{\circ} \mathrm{C}$ T, $98 \% \mathrm{H}, 100 \mu \mathrm{HFW}$; (b) $20 \mathrm{kV}$ AC, $4.5 \mathrm{~S}, 600 \mathrm{~Pa} \mathrm{CP}$, $2^{\circ} \mathrm{C} \mathrm{T}, 85 \% \mathrm{H}, 44.8 \mu \mathrm{m} \mathrm{HFW}$; (c) $10 \mathrm{kV} \mathrm{AC}, 4.5 \mathrm{~S}, 530 \mathrm{~Pa} \mathrm{CP}, 2^{\circ} \mathrm{C} \mathrm{T}$, $74 \% \mathrm{H}, 14.9 \mu \mathrm{m}$ HFW

preparation [40]. Therefore specimens of mouse sperm prepared in TALP were dialyzed against ammonium bicarbonate and ammonium acetate $(\sim 2 \%)$. Optical microscopy did not reveal any changes in the cell appearance after the dialysis. ESEM images of sperm cells were obtained after cautious partial drying of the sample in the ESEM chamber (Figure $2 b$ ).

The second approach, that is, absorbing excess medium with porous substrate, was realized with the use of Nuclepore membrane with $0.1 \mu \mathrm{m}$ channels. The specimen in TALP transferred on the surface of Nuclepore membrane was readily imaged in ESEM with resolution higher than $100 \mathrm{~nm}$ (Figure 2c). Evidently, most of the components of TALP were absorbed by the membrane leaving the cells on the surface of the membrane. Nevertheless, the cells appeared to remain hydrated during the imaging.

Previously, Nuclepore membranes were used in imaging bacteria and other micro-organisms [41-43]. Thus, Nuclepore as a substrate might be useable for imaging other biological specimens in ESEM, possibly including other types of mammalian cells. As specimen preparation for this method requires just a few minutes, the method allows rapid imaging of biological cultures in ESEM at ultrahigh resolution. To the best of our knowledge, Figures $2 b$ and $c$ present the first demonstration of feasibility of imaging hydrated spermatozoa by ESEM.

3.2. In situ observation of probe-cell interactions: Interaction of plant cells with micro- and nanoprobes were monitored in situ in ESEM. Fresh leaves were used for this analysis. The study was performed using a custom-built sample fixture and computerized Microtest in situ mechanical stage (Figure 3). In situ ESEM imaging allowed high-resolution dynamic observation of probe behavior and cell damage during probe-cell interaction.

Figure 4 shows penetration of the leaves' surfaces with glass micropipettes commonly used for microinjection. The outer tip diameter of the micropipettes was in range from 100$300 \mathrm{~nm}$. However, because of the conical shape of the micropipettes, the pipettes make punctures in the leaves with diameters more that $1 \mathrm{~mm}$. The pipettes would create even wider punctures in the cell membrane if the probing target is located deeper inside the cell.

The observed large diameter concave deformation of the leaf surfaces around the sites of the penetrations (Figure 4) is indicative of resistance of the cell walls to penetration. During reverse motion, that is, pipette withdrawal, the surfaces of the leaves followed the pipettes and exhibited convex deformation (Figures $5 a$ and $b$ ), evidently because of the adhesion to the pipette. Figures $5 c$ and $d$ demonstrate commonly observed shapes of punctures in plant leaves after removal of the pipettes. According to the images in Figure 5, the interactions between the two types of cells and the probes were different. Namely, the deformation of the surface of the Arabidopsis

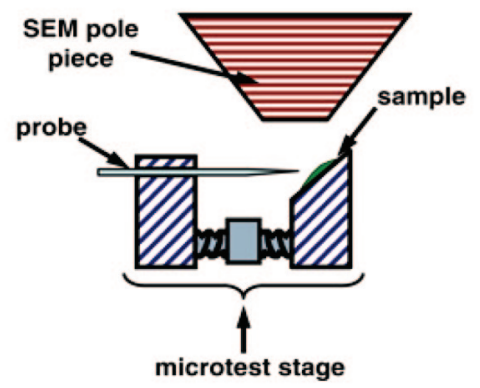

Figure 3. Setup for in situ study of interactions of cells with microinjection probes. Probe is mounted to one of the clamps of Microtest stage so that it is oriented along the axis of movement of the stage. The cells sample on glass surface is mounted to the other clamp at $45^{\circ}$ angle to the axis of the stage so that it can be imaged by electron beam from above

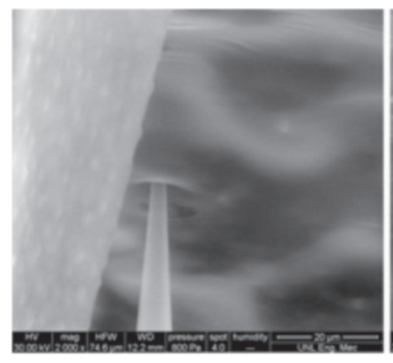

a

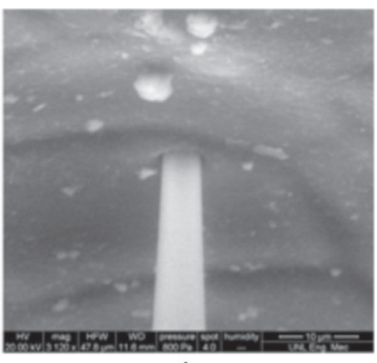

b
Figure 4. Penetration. a. Arabidopsis leaf b. Common bean leaf with glass pipettes Imaging parameters: (a) $30 \mathrm{kV} \mathrm{AC}, 4.0 \mathrm{~S}, 800 \mathrm{~Pa} \mathrm{CP}$, $\sim 34 \% \mathrm{H}, 74.6 \mu \mathrm{m} \mathrm{HFW}$; (b) $20 \mathrm{kV}$ AC, $4.0 \mathrm{~S}, 800 \mathrm{~Pa} \mathrm{CP}, \sim 34 \% \mathrm{H}, 47.8$ $\mu \mathrm{m}$ HFW

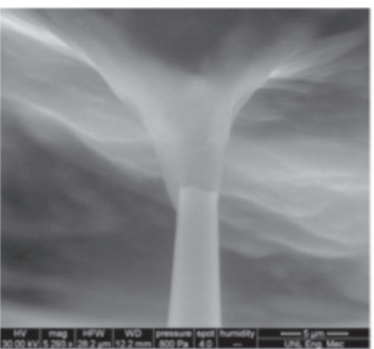

a

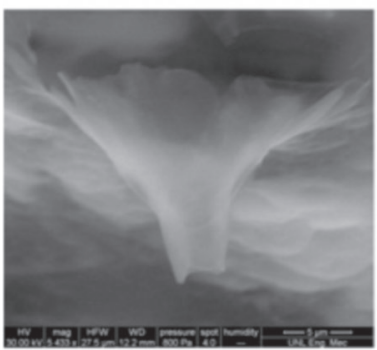

$c$

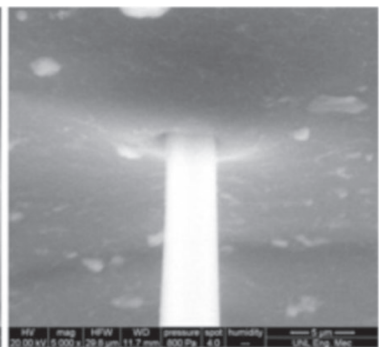

$b$

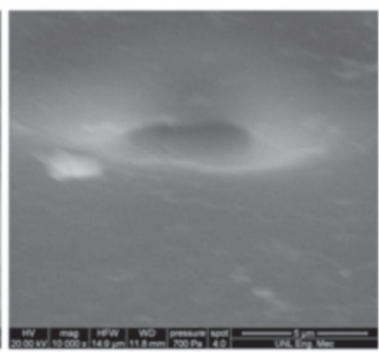

$d$
Figure 5. $(a, b)$ Removal of micropipettes and $(c, d)$ openings left in the leaves after penetration of leaves of $(\mathrm{a}, \mathrm{c})$ Arabidopsis and $(\mathrm{b}, \mathrm{d})$ Common bean by glass micropipettes. Imaging parameters: (a) $30 \mathrm{kV} \mathrm{AC}, 4.0$ S, $800 \mathrm{~Pa} \mathrm{CP}, \sim 34 \% \mathrm{H}, 28.2 \mu \mathrm{m}$ HFW; (b) $20 \mathrm{kV} \mathrm{AC}, 4.0 \mathrm{~S}, 800 \mathrm{~Pa} \mathrm{CP}$, $\sim 34 \% \mathrm{H}, 11.7 \mu \mathrm{m}$ HFW; (c) $30 \mathrm{kV} \mathrm{AC}, 4.0 \mathrm{~S}, 800 \mathrm{~Pa} \mathrm{CP}, \sim 34 \% \mathrm{H}, 27.5$ $\mu \mathrm{m} \mathrm{HFW}$; (d) $20 \mathrm{kV}$ AC, 4.0 S, $700 \mathrm{~Pa}$ CP, $30 \%$ H, $11.8 \mu \mathrm{m}$ HFW

leaf was more substantial. The difference may be owing to higher rigidity of the cell walls of Common bean compared to the Arabidopsis cell walls. Additionally, the difference can be caused by higher adhesion between the probe and the cell content in the case of Arabidopsis. Reducing the adhesion be- 


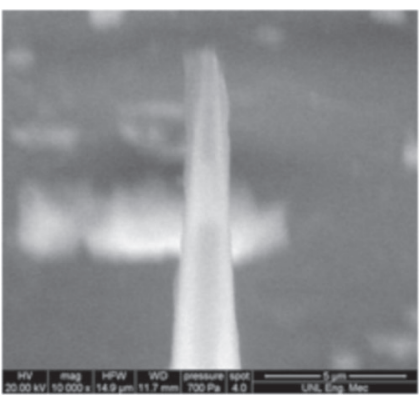

Figure 6. Residue of cellular content left on the surface of micropipette after the penetration of leaf of Common bean. Imaging parameters: 20 kVAC, 4.0 S, $700 \mathrm{~Pa} \mathrm{CP}, \sim 30 \% \mathrm{H}, 11.7 \mu \mathrm{m}$ HFW

tween the probes and the cells may reduce such cell deformation and damage. Figure 6 shows evidence of residue of cellular content left on the surface of a micropipette after the cell wall penetration.

Strong continuous nanopipe-based nanoprobes are expected to alleviate the observed widening of the puncture holes with the increase of penetration depth of the current conical probes. However, uniform-diameter nanopipes may exhibit other problems during penetration, such as buckling and/or breakage. Detailed observations of probe-cell interactions will be critical for the optimal nanoprobe design.

Use of ESEM for this purpose was evaluated by in situ observation of cell interactions with long high-aspect ratio fine capillaries with $\sim 1 \mu \mathrm{m}$ outside diameter and almost cylindrical shape. As seen in Figure 7, the capillaries indeed undergo global buckling during attempted penetration of plant cell wall. Additionally, localized bending near the pipette tip followed by the tip break-off was observed (Figures $7 c$ and $d$ ).

Finally, high-aspect ratio tungsten nanoprobes were fabricated and their interactions with plant leaves were investigated in situ. It was observed that ultra-fine nanoprobes occasionally underwent plastic deformation resulting in permanent plastic bending of the probe tips during penetration of the leaves (Figure 8). Tungsten is considered to be one of the strongest metals. Bending of tungsten nanoprobes demonstrate that nanoinjection of plant cells will demand very rigid or specially constructed nanoprobes. Reinforced nanocomposite probes [44] or hierarchical probes with telescopic extension capability may be considered.

4. Conclusions: The results demonstrate applicability of ESEM for high-resolution imaging of hydrated cells and in situ dynamic observation of probe-cell interactions. ESEM imaging of plant cells was possible in the broad range of parameters and magnifications. Imaging of hydrated yeast cells was achieved at low energy of the electron beam. It was shown that images of mammalian cells such as spermatozoa could be obscured by the residues of culture media. Replacement of traditional media with ammonium acetate/ammonium bicarbonate buffer allowed imaging of mouse spermatozoa by ESEM without any further preparation. Even better image quality was achieved using Nuclepore membrane as a substrate without any other specimen preparation. Intact spermatozoa were observed by the ESEM technique for the first time. The developed specimen preparation and imaging protocols might be useable for other mammalian cells. A summary of imaging conditions that led to successful visualization of investigated cell types is presented in Table 1.

Interaction of several probes with epidermal plant cell walls was observed dynamically in situ for the first time. The observation of cell-probe interactions in ESEM allows studying problems associated with existing probes, such as widening of the puncture hole, adhesion between the probes and the cells, residue of cellular content on the probes, buckling and

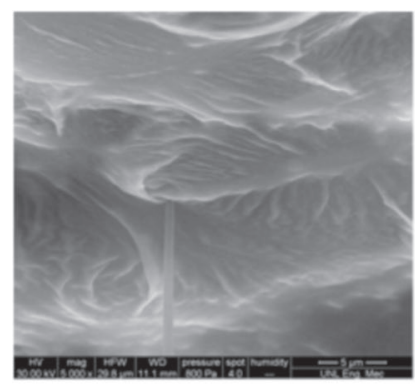

a

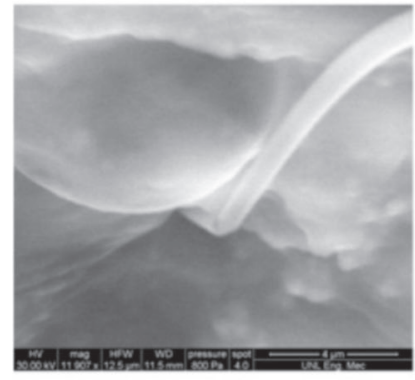

c

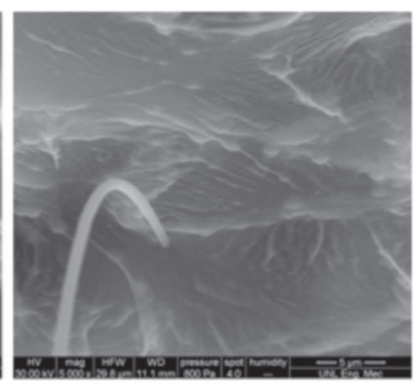

$b$

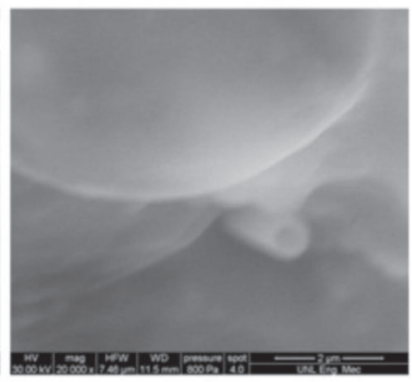

d
Figure 7. Interaction between a glass micropipe and an Arabidopsis leaf. a. Contact between the leaf surface and the micropipe b. Buckling of the micropipe c. Breaking of the micropipe d. Piece of the micropipe left on the leaf surface Imaging parameters: $30 \mathrm{kVAC}, 4.0 \mathrm{~S}, 800 \mathrm{~Pa} \mathrm{CP}$,

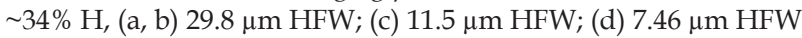

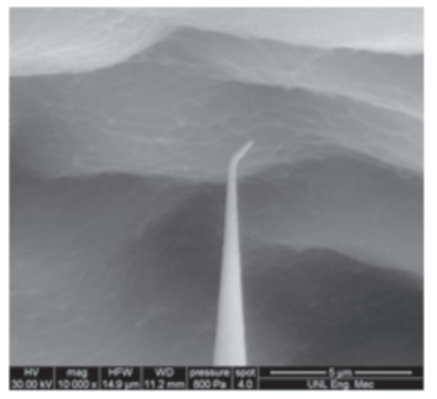

Figure 8. Tungsten nanoprobe bended after penetration of Arabidopsis leaf. Imaging parameters: $30 \mathrm{kVAC}, 4.0 \mathrm{~S}, 800 \mathrm{~Pa} \mathrm{CP}, \sim 34 \% \mathrm{H}, 11.2$ $\mu \mathrm{m}$ HFW

Table 1. Summary of ESEM imaging parameters enabling successful visualization of cells

\begin{tabular}{lccc}
\hline Parameter & Plant cells & Yeast cells & Mouse spermatozoa \\
\hline Accelerating voltage, $\mathrm{kV}$ & $10-30$ & 5 & $10-20$ \\
Spot size setting & $2.5-4.0$ & 2.0 & $4.0-4.5$ \\
Temperature, ${ }^{\circ} \mathrm{C}$ & $2-20$ & 2 & 2 \\
Pressure, $\mathrm{Pa}$ & $700-800$ & 630 & $530-600$ \\
Relative humidity, \% & $30-97$ & 89 & $74-85$ \\
\hline
\end{tabular}

breaking of the probes. Such phenomena cannot be easily assessed by optical microscopy.

Penetration of cell walls with traditional state-of-the-art capillary micropipettes used currently for microinjection created significant damage to the cells, especially for deeper penetrations. This observation establishes the need for the development of smaller, nanoscale probes for minimally invasive cell probing. However, nanoprobes may easily buckle, bend or break during penetration. The conflicting requirements for the minimal cell damage and probe failure may be resolved by employing ultra-rigid nanopipes and/or anti-buckling nanoprobe designs, such as reinforced nanocomposites-based or telescopic designs. 
5. Acknowledgments: The authors thank Alaattin Kaya for his help with yeast samples, Professor Zoya Avramova, School of Biological Sciences, UNL, for assistance with plant cells, and Tadas Kasputis for his help with in situ study of glass micropipette interaction with yeast cells. Partial financial support of this work by grants from the National Science Foundation, National Institutes of Health, and Nebraska Research Initiative is gratefully acknowledged.

\section{References}

[1] Malinow R., Schulman H., Tsien R. Inhibition of postsynaptic PKC or CaMKII blocks induction but not expression of LTP, Science, 1989, 245, pp. 862-866

[2] Husken D., Steudle E., Zimmermann U. Pressure probe technique for measuring water relations of cells in higher plants, Plant Physiol., 1978, 61, pp. 158-163

[3] Desai J. P., Pillarisetti A., Brooks A. D. Engineering approaches to biomanipulation, Annu. Rev. Biomed. Eng., 2007, 9, pp. 35-53

[4] Gordon J. W., Scangos G. A., Plotkin D. J., Barbosa J. A., Ruddle F. H. Genetic transformation of mouse embryos by microinjection of purified DNA, PNAS, 1980, 77, pp. $7380-7384$

[5] Uehara T., Yanagimachi R. Microsurgical injection of Spermatozoa into Hamster eggs with subsequent transformation of sperm nuclei into male pronuclei, Biol. Reprod., 1976, 15, pp. 467-470

[6] Lin J. J., Feramisco J. R. Disruption of the in vivo distribution of the intermediate filaments in fibroblasts through the microinjection of a specific monoclonal antibody, Cell, 1981, 24, pp. 185-193

[7] Freedman J. R., Mattia D., Korneva G., Gogotsi Y., Friedman G., Fontecchio A. K. Magnetically assembled carbon nanotube tipped pipettes, Appl. Phys. Lett., 2007, 90, p. 103108

[8] Wall R. J. Pronuclear microinjection, Cloning Stem Cells, 2001, 3, pp. 209-220

[9] Knoblauch M., Hibberd J. M., Gray J. C., Van Bel A. J. A galinstan expansion femtosyringe for microinjection of eukaryotic organelles and prokaryotes, Nat. Biotechnol., 1999, 17, pp. 906-909

[10] Han S., Nakamura C., Obataya I., Nakamura N., Miyake J. Gene expression using an ultrathin needle enabling accurate displacement and low invasiveness, Biochem. Biophys. Res. Commun., 2005, 332, pp. 633-639

[11] Dzenis Y. Spinning continuous fibers for nanotechnology, Science, 2004, 304, pp. 1917-1918

[12] Butler E. P., Hale K. F. Dynamic experiments in the electron microscope (North-Holland \& New York: Elsevier, 1981)

[13] Peng B., Sun Y., Zhu Y., Wang H., Espinosa H. Nanoscale testing of one-dimensional nanostructures, in Yang F., Li J. C. M., eds., Micro and nano mechanical testing of materials and devices (New York: Springer, 2008)

[14] Zhu Y., Espinosa H. D. An electromechanical material testing system for in situ electron microscopy and applications, PNAS, 2005, 102, pp. 14503-14508

[15] Fahlbusch S., Mazerolle S., Breguet J., et al. Nanomanipulation in a scanning electron microscope, J. Mater. Process. Technol., 2005, 167, pp. 371-382

[16] Noyong M., Blech K., Rosenberger A., Klocke V., Simon U. In situ nanomanipulation system for electrical measurements in SEM, Meas. Sci. Technol., 2007, 18, (1), pp. N84-N89
[17] Peng L. M., Chen Q., Liang X. L., et al. Performing probe experiments in the SEM, Micron, 2004, 35, pp. 495-502

[18] Mølhave K., Wich T., Kortschack A., Bøggild P. Pick-andplace nanomanipulation using microfabricated grippers, Nanotechnology, 2006, 17, pp. 2434-2441

[19] Castillo J., Dimaki M., Svendsen W. E. Manipulation of biological samples using micro and nano techniques, Integr. Biol., 2009, 1, pp. 30-42

[20] Yu M. F., Dyer M. J., Skidmore G. D., et al. Three-dimensional manipulation of carbon nanotubes under a scanning electron microscope, Nanotechnology, 1999, 10, pp. 244-252

[21] Thiel B. L., Donald A. M. In situ mechanical testing of fully hydrated carrots (Daucus carota) in the environmental SEM, Ann. Bot., 1998, 82, pp. 727-733

[22] Bancroft J. D., Gamble M. Theory and practice of histological techniques, 5th edn. (Edinburgh: Churchill Livingstone, 2002)

[23] Watson L. P., McKee A. E., Merrell B. R. Preparation of microbiological specimens for scanning electron microscopy, Scan Electron. Microsc., 1980, 2, pp. 45-56

[24] Postek M. T., Howard K. S., Johanson A. H., McMichael K. L. Scanning electron microscopy: A student's handbook (Burlington, VT: Ladd Research Industries, 1980)

[25] Hayat M. A. Principles and techniques of electron microscopy: Biological applications, 4th edn. (Cambridge: Cambridge University Press, 2000)

[26] Donald A. M. The use of environmental scanning electron microscopy for imaging wet and insulating materials, Nat. Mater., 2003, 2, pp. 511-516

[27] Danilatos G. D. The examination of fresh or living plant material in an environmental scanning electron microscope, J. Microsc., 1981, 121, pp. 235-238

[28] Danilatos G. D. Foundations of environmental scanning electron microscopy, Adv. Electron. Electron Phys., 1988, 71, pp. 109-250

[29] Danilatos G. D., Denby E. F., Algie J. E. The effect of relative humidity on the shape of Bacillus apiarius spores, Curr. Microbiol., 1984, 10, pp. 313-316

[30] Baumgarten N. Environmental SEM premieres, Nature, 1989, 341, pp. 81-82

[31] Betrabet H. S., McKinlay J. K., McGee S. M. Dynamic observations of $\mathrm{Sn}-\mathrm{Pb}$ solder reflow in a hot-stage environmental scanning electron microscope, J. Mater. Sci., 1992, 27, pp. 4009-4015

[32] Manero J. M., Gil F. J., Padrus E., Planell J. A. Applications of environmental scanning electron microscopy (ESEM) in biomaterials field, Microsc. Res. Tech., 2003, 61, pp. 469-480

[33] Schalek R. L., Drzal L. T. Characterization of advanced materials using an environmental SEM, J. Adv. Mater., 2000, 32, pp. 32-38

[34] Schmid B., Aas N., Grong Ø., Ødegfrd R. High-temperature oxidation of nickel and chromium studied with an in-situ environmental scanning electron microscope, Scanning, 2001, 23, pp. 255-266

[35] Jenkins L. M., Donald A. M. Use of the environmental scanning electron microscope for the observation of the swelling behaviour of cellulosic fibres, Scanning, 1997, 19, pp. 92-97

[36] Donald A. M., He C., Royall C. P., Sferrazza M., Stelmashenko N. A., Thiel B. L. Applications of environmental scanning electron microscopy to colloidal aggregation and film formation, Colloids Surf. Physicochem. Eng. Aspects, 2000, 174, pp. 37-53 
[37] Bergmans L., Moisiadis P., Van Meerbeek B., Quirynen M., Lambrechts P. Microscopic observation of bacteria: Review highlighting the use of environmental SEM, Int. Endod. J., 2005, 38(14), pp. 775-788

[38] Ahmad M. R., Nakajima M., Kojima S., Homma M., Fukuda T. The effects of cell sizes, environmental conditions, and growth phases on the strength of individual W303 yeast cells inside ESEM, IEEE Trans. Nanobiosci., 2008, 7, pp. 185-193

[39] Ren Y., Donald A. M., Zhang Z. Investigation of the morphology, viability and mechanical properties of yeast cells in environmental SEM, Scanning, 2008, 30, pp. 435-442

[40] Backus R. C., Williams R. C. The use of spraying methods and of volatile suspending media in the preparation of specimens for electron microscopy, J. Appl. Phys., 1950, 21, pp. 11-15
[41] Priester J. H., Horst A. M., Van De Werfhorst L. C., Saleta J. L., Mertes L. A. K., Holden P. A. Enhanced visualization of microbial biofilms by staining and environmental scanning electron microscopy, J. Microbiol. Methods, 2007, 68, pp. 577-587

[42] Maki J. S., Remsen C. C. A membrane adsorption-SEM technique for observing neuston organisms, Microb. Ecol., 1983, 9, pp. 177-183

[43] Paerl H. W., Shimp S. L. Preparation of filtered plankton and detritus for study with scanning electron microscopy, Limnol. Oceanogr., 1973, 18, pp. 802-805

[44] Dzenis Y. Structural nanocomposites, Science, 2008, 319, pp. $419-420$ 